Agro-Science Journal of Tropical Agriculture, Food, Environment and Extension Volume 16 Number 1 (January 2017) pp. $31-35$

ISSN 1119-7455

\title{
MAIZE COB LOSSES AND THEIR EFFECTS ON THE POVERTY STATUS OF MAIZE FARMERS IN EDO STATE, NIGERIA
}

\author{
"Okoror, O.T. and Ahmadu, J. \\ Department of Agricultural Economics \& Extension Services, Faculty of Agriculture, \\ University of Benin, Benin City, Nigeria
}

*Corresponding author's email: okiemua.okoror@uniben.edu

\begin{abstract}
This study analysed fresh maize cob losses and its effect on the poverty status of maize farmers in Edo State, Nigeria. The specific objectives were to estimate the physical and financial amount of fresh maize cob losses experienced by maize farmers, examine the effect of fresh maize cob losses on the respondents' poverty status, and determine the poverty status of the respondents. Multistage sampling technique was used in selecting 108 maize farmers. The data were analysed using descriptive statistics, budgeting technique, relative poverty line analysis, the Foster-Greer-Thorbecke (FGT) poverty measure, and t-test. The average profit without loss per maize farmer was $\$ 165,599.15$. However, with loss of about $185 \mathrm{~kg}$ of fresh maize cobs per farmer, the profit reduced to $\$ 118,931.17$. The difference in the mean profit with and without loss was significant at 1\%. Fresh maize cob losses increased the proportion of the poor respondents by $14 \%$. The poverty incidence with and without maize cob loss was 0.64 and 0.50 respectively. The study concluded that maize farming was a profitable venture. However, maize cob loss resulted in significant reduction in the income of the farmers. This study therefore recommended that relevant bodies such as the government, farmers' cooperatives and non-governmental organizations should assist in addressing the problem of maize cob loss among farmers which would help alleviate their poverty.
\end{abstract}

Key words: relative poverty line, FGT poverty measure, budgetary technique

\section{INTRODUCTION}

Maize is an important cereal crop that originated from South and Central America and came into West Africa in the $10^{\text {th }}$ century (Ukonze et al., 2016; Olaniyi and Adewale, 2012) and to Nigeria in the $16^{\text {th }}$ century. Maize is a widely accepted crop cultivated in most parts of the country in several varieties. The most common types are yellow, white and red maize (Iken and Amusa, 2004). Maize which started as a subsistence crop in Nigeria is now grown on commercial basis due to its economic importance. It thrives well in diverse ecological zones; it is consumed either as a snack or substitute for normal food, serves as a source of carbohydrate to humans, feed for livestock, raw material for many industries and source of income, thereby seen as a panacea for poverty in Nigeria (Olaniyan 2015). Its grains are said to be rich in essential minerals, protein, fats, fibre and carbohydrates (Sule et al., 2014).

In terms of production (area harvested), maize is the third largest cereal produced worldwide after wheat and rice (Olaniyan 2015). Africa accounts for $7 \%$ of the global maize production and $12 \%$ of the global maize imports. Nigeria is the largest producer of maize in Sub-Saharan Africa. Its production in 2010 accounted for $0.9 \%$ (7.7 million tons) of world production (844 million tons) (FARA, 2009). However, with the importance of maize and the level of the country's production, it is still faced with diverse constraints. Amongst such diverse constraints are: pests and diseases, low soil fertility, lack of /inadequate technology, inadequate capital, unavailability of labour, poor road network, lack of transportation, weather factors, high labour cost, high cost of storage facilities, lack of technical know-how and poor storage facilities, which result in maize losses. Survey carried out on food loss in some communities in Nigeria found that as much as $20-$ $30 \%$ of total grain production (maize inclusive) is lost with a substantial amount recorded during storage (Bolarin and Bosa, 2015).

Maize loss is experienced by all stake holders in the maize food chain including producers. However, most research on maize loss focus on losses experienced by marketers and processors and not on producers. Is there a possibility that this is so because maize loss at the producers' level is insignificant or not in existence? It is therefore very 
important for this study to answer this question by analysing the losses experienced by maize producers. These losses could occur during production, harvesting, immediately after harvest if they are unable to sell all that is produced and during transportation. This could also have an effect on their level of poverty; the material, social, and emotional deprivation of individuals or group (Tomlinson et al., 2008). This study therefore seeks to answer the following research questions: What is the physical and financial value of loss experienced by maize producers? What is the poverty status of the maize producers? What is effect of maize cob losses experienced by the farmers on their poverty status? The general objective of the study is maize cob losses and their effects on the poverty status of maize farmers in Edo State. The specific objectives are to determine: the physical and financial value of loss experienced by maize producers, the poverty status of maize producers and the effect of maize cob losses on the poverty status of the farmers. The hypothesis of the study- Ho: no significant difference in the income of the respondents with and without fresh maize cob losses.

\section{MATERIALS AND METHODS}

This study was carried out in Edo State, Nigeria and comprised of maize producers. Edo State has a total land area of $17,802 \mathrm{~km}^{2}$ and an estimated population of over three million people. The state is made up of 18 Local Government Areas (LGAs). The three agro-ecological zones of the state as delineated by Edo State Agricultural Development Programme (EADP) are Edo South, Edo Central and Edo North. Edo State has a tropical climate characterized by wet and dry seasons having mean annual temperature of about 25 and $28^{\circ} \mathrm{C}$, respectively. The climate and soil condition favours the growth of plants. Specifically a well drained sandy, loam to clayey loam soil rich in humus and plant nutrients is ideal for maize production (Anyanwu, 1979). The minimum temperature requirement for maize is $10^{\circ} \mathrm{C}$ and maximum temperature of about $46^{\circ} \mathrm{C}$. Maize is an important food crop that is grown all over the state for its economic value as food, source of income and source of employment amongst others. Other crops grown in the state are cassava, yam, vegetables, pineapple, oil palm, cocoa, rubber, etc.

\section{Study Area}

\section{Sampling procedure and sample size}

The study employed a multi-stage sampling procedure for the selection of respondents. Firstly, two local government areas (LGAs) were randomly selected from each of the three agro-ecological zones (Edo South, Central and North) of the State as delineated by Edo State Agricultural Development Programme (EADP) to give a total of 6 LGAs. Secondly, two communities involved in maize production were randomly selected from each LGA making a total of 12 communities selected for the study. The third stage was a random selection of 9 producers from each community giving rise to a total of 108 maize producers.

\section{Data Analysis}

\section{Budgeting technique}

The budgeting techniques employed were the gross margin and the net profit analyses. These were used to determine the profitability of maize production. according to Olukosi and Erhabor (1988):

$$
\mathrm{GM}=\mathrm{TR}-\mathrm{TVC}
$$

where GM is gross margin of maize production $(\mathrm{N})$, TR is total revenue from maize production ( $)$ TR is the product of the unit price of maize $(\mathrm{P})$ and quantity(ies) sold (Q), TVC is total variable cost of maize production ( $)$ which is the sum total of labour cost (LC), seed cost (SC), fertilizer cost (FC), herbicides cost (HC), pesticides cost (PC), and transportation cost (TC).

The net profit is given as:

$$
\pi=\mathrm{GM}-\mathrm{TFC}
$$

where $\pi$ is net profit of maize production ( $)$, GM

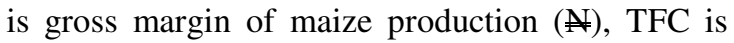
total fixed cost ( $N$, TFC is rent on land (RL) plus total depreciated cost (TDC).

Return on investment of maize production (ROI) is obtained of $\pi$ to total cost.

\section{Relative poverty line analysis}

Relative poverty was used to evaluate the poverty status of the respondents. This was achieved employing the monetary (income) indicator. Respondents were categorized into poor and nonpoor groups using two-third mean per-capita income as poverty line as used by Edoumiekumo et al. (2014) and Igbalajobi et al. (2013). Poverty line using income approach is defined as per-capita income (PCI) which is income per head per day.

$$
\text { Total per } \text {-capita income }(\mathrm{TPCI})={ }_{i=1}^{n} \sum \mathrm{PCI}
$$

Mean TPCI (MTPCI) is TPCI divided by the total number of households.

$$
\text { Poverty Line }(\mathrm{PL})=2 / 3 \times \text { MTPCI }
$$

Poor households were households whose mean percapita income fell below the poverty line, while the non poor were households with mean per-capita income on and above the poverty line. 


\section{Poverty indexes analysis}

The Foster, Greer Thorbecke (FGT) (1984) poverty measure was used to assess the poverty status of the maize producers. It is defined as:

$$
\mathrm{P}_{\alpha}=\frac{1}{n} \sum_{i=1}^{q}\left(\frac{z-y_{i}}{z}\right)^{\alpha}
$$

where $\mathrm{n}$ is the sample size, $\mathrm{q}$ is the number of poor households, $y_{i}$ is the income of the $\mathrm{i}^{\text {th }}$ farmer, $Z$ is the poverty line and, $z-y_{i}$ is the poverty gap for each household and $\alpha$ is a parameter which takes values 0 for poverty incidence.

\section{Use of $t$-test}

T-test was used to test the hypotheses. The t-test is given as:

$$
\mathrm{t}=\frac{z_{1}-z_{2}}{\sigma z_{1}-z_{2}}
$$

where $t$ is t-test, $\sigma \bar{X}_{1}-\bar{X}_{2}=\sqrt{\frac{\sigma_{1}^{2}}{n_{1}}+\frac{\sigma_{2}^{2}}{n_{2}}}, \bar{X}_{1}$ is mean income of maize producers without post harvest losses, $\bar{X}_{2}$ is mean income of maize producers with post harvest losses, $\sigma_{1}$ is standard deviation of income of maize producers without post harvest losses, $\sigma_{2}$ is standard deviation of income of maize producers with post harvest losses, and $n_{1}=n_{2}$ is the sample size of respondents.

\section{RESULTS AND DISCUSSION}

Costs and Returns of Maize Production per Farmer per Production Cycle with and without Maize Cob Losses

The results of the costs and returns of maize production with and without maize cob losses (Table 1) showed that the total variable cost and total fixed cost of maize production per average farm size of the farmers (1.46 ha) per production cycle were $\$ 144,733.21$ and $\$ 17,634.31$ respectively, giving rise to total cost of $\$ 162,367.48$.

The total variable cost accounted for $89 \%$ of the total cost while the depreciated total fixed cost accounted for $11 \%$. The low fixed costs indicate that the farmers, who were mainly small scale farmers, used crude implements (hoes and cutlasses) for their production. Labour cost accounted for $76 \%$ ( $\$ 123,840.06)$ of the total cost of production followed by rent on land which accounted for $9 \%$ $(\mathbb{1 4}, 849.77)$ of the total cost of production as shown in Table 1. This suggests that hired labour was not readily available in the study area which could have resulted in the high labour cost. Also, the use of crude implements and human labour as against the use of machinery could have also contributed to the high labour cost.
Table 1: Average Costs and returns of maize production

\begin{tabular}{|c|c|c|c|}
\hline Category & & $\begin{array}{l}\text { Value per } \\
\text { average } \\
\text { farmer }(\mathbb{N})\end{array}$ & $\begin{array}{l}\text { Total } \\
\text { cost } \\
(\%)\end{array}$ \\
\hline $\begin{array}{l}\text { Mean farm } \\
\text { size (ha) }\end{array}$ & 1.46 & & \\
\hline Man-days per ha & 118.00 & & \\
\hline $\begin{array}{l}\text { Average price } \\
\text { per man-day }(\AA)\end{array}$ & 719.70 & & \\
\hline \multicolumn{4}{|l|}{ Variable costs } \\
\hline Labour Cost & & $123,840.06$ & 76.27 \\
\hline Seed cost & & $6,062.00$ & 3.73 \\
\hline Fertilizer cost & & $4,346.27$ & 2.68 \\
\hline Herbicides cost & & $3,059.29$ & 1.88 \\
\hline Pesticides cost & & $1,262.96$ & 0.78 \\
\hline $\begin{array}{l}\text { Transportation } \\
\text { cost }\end{array}$ & & $6,162.63$ & 3.80 \\
\hline $\begin{array}{l}\text { Total Variable } \\
\text { cost }\end{array}$ & & $144,733.21$ & 89.14 \\
\hline \multicolumn{4}{|l|}{ Fixed cost } \\
\hline Rent on land & & $14,849.77$ & 9.15 \\
\hline Depreciated cost & & $2,784.54$ & 1.71 \\
\hline Total fixed cost & & $17,634.31$ & 10.86 \\
\hline Total cost & & $162,367.48$ & 100.00 \\
\hline \multicolumn{4}{|l|}{ Returns } \\
\hline $\begin{array}{l}\text { Total expected } \\
\text { yield }(\mathbb{N})\end{array}$ & & $327,966.63$ & - \\
\hline $\begin{array}{l}\text { Total expected } \\
\text { yield per ha }(\AA)\end{array}$ & & $224,634.68$ & - \\
\hline $\begin{array}{l}\text { Average weight } \\
\text { per bag }(\mathrm{kg})\end{array}$ & 100.00 & & - \\
\hline $\begin{array}{l}\text { Gross margin } \\
\text { without loss }\end{array}$ & & $168,576.13$ & - \\
\hline $\begin{array}{l}\text { Profit } \\
\text { without loss }\end{array}$ & & $165,599.15$ & - \\
\hline $\begin{array}{l}\text { Return on } \\
\text { investment }\end{array}$ & & 1.02 & - \\
\hline $\begin{array}{l}\text { Output lost } \\
\text { (bags) }\end{array}$ & 1.85 & $46,721.31$ & - \\
\hline $\begin{array}{l}\text { Output lost } \\
\text { per ha (bags) }\end{array}$ & 1.27 & 32000.90 & \\
\hline $\begin{array}{l}\text { Average weight } \\
\text { per Bag }(\mathrm{kg})\end{array}$ & 100.00 & & - \\
\hline Actual yield & & $281,298.65$ & - \\
\hline $\begin{array}{l}\text { Actual yield } \\
\text { per ha }\end{array}$ & & $192,670.31$ & \\
\hline $\begin{array}{l}\text { Gross margin } \\
\text { with loss }\end{array}$ & & $121,854.81$ & - \\
\hline Profit with loss & & $118,931.17$ & - \\
\hline $\begin{array}{l}\text { Return on } \\
\text { investment }\end{array}$ & & 0.73 & - \\
\hline
\end{tabular}
with and without maize cob losses per production cycle

A similar result of labour cost accounting for a large percentage of the total cost of production was reported by Nkamigbo et al. (2015) in a study carried out in Osun State, Nigeria, on comparative analysis of costs and returns in maize production. Seed cost ( 6,062) accounted for about $4 \%$ of the total cost of production, fertilizer cost $(\$ 4,346.27)$ 
accounted for about $3 \%$ of the total cost of production, pesticides cost $(\$ 1,262.96)$ accounted for $0.78 \%$, while transportation cost $(\$ 6,162.63)$ accounted for about $4 \%$ of the total cost of production. These costs were quite low. The results in Table 1 also showed that the gross margin and net profit of maize production per average farm size of 1.46 ha per farmer without post harvest loss were $\$ 168,576.13$ and $\$ 165,599.15$, respectively. This indicates that maize production in the study area was profitable. The return on investment without post harvest losses was $\$ 1.02$ which indicated that every naira invested in the business yielded a net return of 1 naira 2 kobo. Nkamigbo et al. (2015) reported a positive profit of about $\$ 76,055$ for non hybrid maize per hectare of maize land and $\$ 114,450$ for hybrid maize per hectare in Osun State, Nigeria. Also, Aina et al. (2015) reported a positive profit among maize farmers in their study carried out in the dry savannah ecological zone of Nigeria.

However, with losses of $185 \mathrm{~kg}$ of fresh maize cob per average farmer amounting to $\$ 46,721.31$, the gross margin and net profit decreased to $\$ 121,854.81$ and $\$ 118,931.17$, respectively. The return on investment also decreased to 0.73 . The implication of this is that maize cob losses reduced the income of the respondents, as for every Naira invested the business yielded about 73 kobo as against 1 Naira 2 kobo without loss. This could mean that maize cob loss is a factor militating against poverty alleviation among farmers in the study area. This is in line with the findings of Olayemi et al. (2012). They reported a percentage loss of $20.33 \%$ by maize farmers across the three delineated zones in River State, Nigeria. Abass et al. (2014) reported loss in maize during harvesting and transportation in a study carried out in
Tanzania. Also, Oguntade (2013) reported that farmers experience losses during harvest and immediately after harvesting and in course of production attributable to pests and diseases.

\section{Effect of fresh maize cob loss on the income of respondents in Edo State}

The difference in mean income (profit) of the respondents with and without fresh maize cob losses as presented in Table 2 shows that there was a significant difference in the mean income of farmers with and without maize cob loss with significant $(p<0.01) t$-value of 3.65. The implication of this is that maize cob loss significantly affected the income of maize producers. This could invariably have effect on their economic wellbeing as maize is a significant driving force for poverty reduction (Diao et al., 2013).

\section{Poverty indices with and without maize cob losses of respondents in Edo State}

The relative poverty line of the maize farmers was estimated as $\$ 100.40$ (Table 3). The result of the study as presented in Table 3 shows that with maize cob loss, $64 \%$ of the maize farmers were poor and were living below the poverty line. The result was different without maize cob loss as there was an improvement in the well-being of the farmers. This was seen in the percentage drop in the proportion of the poor farmers from $64 \%$ to $50 \%$. This also means that the poverty incidence with and without maize cob loss was 0.64 and 0.50 respectively. This indicates that maize cob loss decreased the income level of the farmers thereby making them worse off. The estimated poverty line was very low ( $\$ 100.40)$ in comparison with the present economic situation, this can barely give you a good meal.

Table 2: Effect of fresh maize cob loss on the income of respondents in Edo State

\begin{tabular}{llllll}
\hline Category & Without loss & With loss & Difference & t-value & Decision \\
\hline Farmers mean income $(N)$ & $165,599.20$ & $118,931.10$ & $46,668.10$ & $3.65^{* * *}$ & Reject Ho \\
\hline$* * *$ significant at 1\% & & & &
\end{tabular}

Table 3: Distribution of the poverty indices with and without fresh maize cob losses of respondents in Edo State

\begin{tabular}{lcccc}
\hline & \multicolumn{2}{c}{ Without maize cob losses } & \multicolumn{2}{c}{ With maize cob losses } \\
Producers & Frequency & Percentage (\%) & Frequency & Percentage $(\%)$ \\
\hline Poor (Per capita income $<100.40)$ & 54 & 50 & 69 & 64 \\
Non poor (Per capita income $\geq 100.40)$ & 54 & 50 & 39 & 36 \\
Total & 108 & 100 & 108 & 100 \\
Poverty incidence & 0.5 & & 0.64 & \\
\hline
\end{tabular}




\section{CONCLUSION}

The study concludes that maize production in the study area is a profitable venture. The respondents experienced maize cob loss which decreased their profit. The loss in income experienced by the maize farmers was significant as it increased the proportion of the poor respondents in the study area. More farmers should be encouraged into maize production as it is a profitable venture which could assist in alleviating their poverty. However, the study recommends that relevant bodies should assist in addressing the problem of maize cob loss among farmers to help in alleviating their poverty.

\section{ACKNOWLEDGMENTS}

We wish to express our profound gratitude to the Executive Secretary, Tertiary Education Trust Fund (TETFund), Prof. S.E. Bogoro for approving the grant for this study. To the immediate past Vice Chancellor of the University of Benin, Prof. O.G. Oshod in under whose administration the TETFund grant was approved, we are utmost grateful for approving our proposal and for providing enabling environment to conduct the research. To the present Vice Chancellor of the University, Prof, F.F.O. Orumwense and his management team, we are indeed very grateful for continuing with the creation of conducive atmosphere for us to work and effectively conduct our research.

\section{REFERENCES}

Abass, A.B., Ndunguru, G., Mamiro, P., Alenkhe, B., Mlingi, N. and Bekunda, M. (2014). Post-harvest food losses in a maize-based farming system of semi-arid savannah area of Tanzania. Journal of Stored Products Research, 57, 49-57

Aina O.S., Ajijola S., Odetola, S.K., Usman, J.M. and Daniel, J.E. (2015). Evaluation of earning performance of maize enterprise in the dry savannah. ecological zone, Nigeria. International Journal of Agriculture, Forestry and Fisheries, $3(2), 52-56$

Anyanwu, A.E., Anyanwu, B.O. and Ayanwu, V.A. (1979). A text book of Agriculture for school certificate, Singapore: F.E.P. international limited.

Bolarin, F.M. and Bosa, S.O. (2015). Post harvest losses: A dilemma in ensuring food security in Nigeria. Jour. of Natural Sciences Research, 5(7), 151-154

Diao, X., Kennedy, A., Mabiso, A., Pradesha, A. (2013). Economy wide impact of maize Export bans on agricultural growth and household welfare in Tanzania. A dynamic computable general equilibrium model analysis. IFPRI Discussion Paper 01287. Development strategy and governance division. Available online at:

http://www.ifpri.org/sites/default/files/publications/ifpr idp01287.pdf
Edoumiekumo, S.G., Karimo T.M. and Tombofa S.S. (2014). Income poverty in Nigeria: incidence, gap, severity and correlates. American Journal of Humanities and Social Sciences, 2(1), 1-9

FARA (2009). Forum for Agricultural Research in Africa (FARA). Patterns of change in maize production in Africa: Implications for maize policy development. Networking Support Function 3. Regional Policies and Markets. Ministerial Policy Brief Series

Foster, J., Greer, J. and Thorbecke E. (1984). A class of decomposable poverty measures. Econometrica, 52, 761-766

Igbalajobi, O., Fatuase, A.I. and Ajibefun, I. (2013). Determinants of poverty incidence among rural farmers in Ondo State, Nigeria. American Journal of Rural Development, 1(5), 131-137

Iken, J.E. and Amusa, N.A. (2004). Maize research and production in Nigeria. African Journal of Biotechnology, 3(6), 302-307

Nkamigbo, D.C., Atiri, O.A., Gbughemobi, B.O. and Obiekwe, N.J. (2015). Comparative analysis of costs and returns in hybrid and non hybrid maize production in Osun State, Nigeria. Journal of Agriculture and Veterinary Sciences, 7 (2), 56-70

Oguntade, A.E. (2013). Food losses in cassava and maize value chains in Nigeria. Analysis and recommendations for reduction strategies. German Federal Ministry for Economic Cooperation and Development; Division Rural Development, Agriculture and Food Security. Deutsche Gesellschaft fur Internationale Zusammenarbeit (GIZ) GmbH, Germany

Olaniyi, O.A. and Adewale, J.G. (2012). Information on maize production among rural youth: A solution for sustainable food security in Nigeria. Library Philosophy and Practice (e-journal), 4 (1), 1-13 http://digitalcommons.unl.edu/libphilprac/724

Olaniyan, A.B. (2015). Maize: Panacea for hunger in Nigeria. African Journal of Plant Science, 9(3), 155-174

Olayemi, F.F., Adegbola, J.A., Bamishaiye, E.I. and Awagu, E.F. (2012). Assessment of post harvest losses of some selected crops in eight local government areas of Rivers State, Nigeria. Asian Journal of Rural Development, 2(1), 13-23

Olukosi, S.O. and Erhabor, P.O. (1988). Introduction to farm management economics: Principles and Applications. Agitab Publishers Ltd., Zaria, Nigeria.

Sule, E.I., Umoh, V.J., Whong, C.M.Z., Abdullahi, I.O. and Alabi, O. (2014). Chemical and nutritional value of maize and maize products obtained from selected markets in Kaduna State, Nigeria. African Jour. of Food Science \& Technology, 5 (4), 100-104

Tomlinson, M., Walker, R and Williams, G. (2008). measuring poverty in Britain as a multidimensional concept, 1991 to 2003. Journal of Social Policy, 37, 597-620

Ukonze, J.A., Akor, V.O. and Ndubuaku, U.M. (2016). Comparative analysis of three different spacing on the performance and yield of late maize cultivation in Etche Local Government Area of Rivers State, Nigeria. African Journal of Agricultural Research, 11(13), 1187-1193 